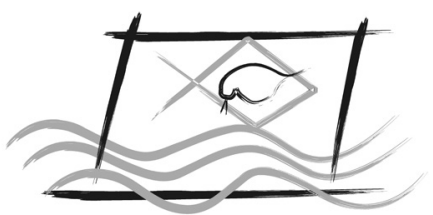

ECOTOX - BRASIL

\title{
Cytotoxicity evaluation of Amoxicillin and Potassium Clavulanate in Perna perna mussels
}

\author{
Souza, A..$^{*}$; Moreno, B.B. ${ }^{2} ;$ Almeida, J.E. ${ }^{3} ;$ Rogero, S.O. ${ }^{1}$; Pereira, C.D.S. ${ }^{3}$ \& Rogero, J.R. ${ }^{1}$ \\ 1- Laboratório de Ecotoxicologia e Citotoxicidade - Centro de Química e Meio Ambiente - Instituto de Pesquisas Energéticas e Nucleares \\ (IPEN) - Comissão Nacional de Energia Nuclear - IPEN/CNEN-SP, SP, Brasil. \\ 2- Laboratório de Ecotoxicologia - Universidade Santa Cecília, Santos - SP, Brasil. \\ 3- Departamento de Ciências do Mar - Universidade Federal de São Paulo, Santos - SP, Brasil.
}

(Received January 19, 2016; Accept June 13, 2016)

\begin{abstract}
Pharmaceutical compounds are identified in environmental matrices in the order of magnitude of $n g \mathrm{~L}^{-1}$ to $\mu \mathrm{g} \mathrm{L}^{-1}$. Among the drugs, antibiotics have been receiving special attention due to the problems caused to aquatic biota. The aim of this study was to evaluate the cytotoxicity of Amoxicillin and Potassium Clavulanate, in isolated and associated forms, to marine mussels Perna perna through neutral red retention time assay (NRRT), which assesses the stability of lisossomal membrane of testorganisms hemocytes. Amoxicillin caused cytotoxicity to the mussels in concentrations of OEC $=1 \mathrm{ng} \mathrm{L}^{-1}, \mathrm{IC}_{25-24 \mathrm{~h}}=0.44 \mathrm{ng} \mathrm{L}^{-1}$, $\mathrm{IC}_{25-48 \mathrm{~h}}=1.19 \mathrm{ng} \mathrm{L}^{-1}$ and $\mathrm{IC}_{25-72 \mathrm{~h}}=0.85 \mathrm{ng} \mathrm{L}^{-1}$, Potassium Clavulanate was cytotoxic at concentrations of $\mathrm{OEC}=10 \mathrm{ngL}^{-1}$ in $24 \mathrm{~h}$; $50 \mathrm{ng} \mathrm{L}^{-1}$ and $100 \mathrm{ng} \mathrm{L}^{-1}$ at $48 \mathrm{~h}$ and $72 \mathrm{~h}$. The inhibitory concentration values $\left(\mathrm{IC}_{25}\right)$ were: $3.11 \mathrm{ng} \mathrm{L}^{-1}, 3.45 \mathrm{ng} \mathrm{L}^{-1}$ and $3.43 \mathrm{ng}$ $\mathrm{L}^{-1}$ at $24 \mathrm{~h}, 48 \mathrm{~h}$ and $72 \mathrm{~h}$ respectively. In the test conducted with the combination of drugs, all concentrations were cytotoxic to mussels in 48h. In 72h only $40 \mathrm{ng} \mathrm{L}{ }^{-1}$ Amoxicillin $+10 \mathrm{ng} \mathrm{L}^{-1}$ Potassium Clavulanate and $200 \mathrm{ng} \mathrm{L}^{-1}$ Amoxicillin $+50 \mathrm{ng} \mathrm{L}^{-1}$ Potassium Clavulanate were cytotoxic. The $\mathrm{IC}_{25}$ for Amoxicillin was $1.67 \mathrm{ng} \mathrm{L}^{-1}$ in $48 \mathrm{~h}$ and $1.36 \mathrm{ng} \mathrm{L}^{-1}$ in $72 \mathrm{~h}$. For Potassium Clavulanate was $0.42 \mathrm{ng} \mathrm{L}^{-1}$ in $48 \mathrm{~h}$ and in $72 \mathrm{~h}$ was $0.34 \mathrm{ng} \mathrm{L}^{-1}$.
\end{abstract}

Key-words: Cytotoxicity; Perna perna; Neutral Red; Amoxicillin; Potassium Clavulanate; Pharmaceutical compounds; Micropollutant.

\section{INTRODUCTION}

Pharmaceutical compounds are produced to accomplish a specific therapeutical purpose, however, after the consumption are excreted almost unaltered (Cooper et al., 2008). They are part of a micro pollutants class that is found in low concentrations in the aquatic environment, in the order of nanograms to micrograms per liter (Bila \& Dezotti, 2003).

The current model applied in sewage treatment plants is not sufficient to remove all drug residues. The effluents obtained after the treatment are discharged in environment water such as rivers and seas, which provide the persistence of these substances. The presence of these compounds originated from illegal sewage systems, the leaching of contaminated soil, and incorrect discharge of drugs have aroused the attention of the scientific community, once that it is necessary to understand the damages caused to biota and water quality. This way preventive and mitigatory action can be taken to control the conscious use of medications and their correct way of disposal and removal (Cooper et al., 2008; Regitano \& Leal, 2010).

The antibiotics have been receiving more attention once the low concentrations allow the formation of more resistant bacteria lines (Zou et al., 2011). The antibiotics are also used in veterinary, agriculture and aquaculture (Kümmerer, 2009). In this group, the beta-lactam class penicillin is the best known. This class is considered a milestone since their discovery by Alexander Fleming, for it allowed advances in infection treatments, and is still used nowadays (Ozcengiz et al., 2013). Amoxicillin is the most representative drug due to its wide prescription and worldwide use. It acts by 
inhibiting the cell wall synthesis of Gram-positive and Gram-negative bacteria.

Amoxicillin has already been detected in some regions at concentrations as: $<10 \mathrm{ng} \mathrm{L}^{-1}$ in surface water in Northwest Germany (Christian et al., 2003), > $120 \mathrm{ng} \mathrm{L}^{-1}$ in sewage treatment plants in Italy (Andreozzi et al., 2004), $190 \mathrm{ng} \mathrm{L}^{-1}$ in Australia and $12.64 \mu \mathrm{g} \mathrm{L}^{-1}$ for affluent wastewater (Watkinson et al., 2007; Lee et al., 2008).

Nonetheless, with the resistance of some microorganism to Amoxicillin, it has become necessary to include another component to improve the effectiveness of the drug. Consequently, the compound found was the Clavulanic Acid isolated from Streptomyces clavuligerus bacteria (Saudagar $e t$ al., 2008).

The Clavulanic Acid is used in the form of Potassium Clavulanate. By itself, this compound has weak antibiotic action, however, associated to Amoxicillin, it inhibits the beta-lactamase enzyme, which interrupts the peptioglycan synthesis that is part of the structure of the cell wall.

The environmental information is scarce for this drug, although, based on this drug's consumption data in France, Besse \& Garric (2008) estimated the presence of Potassium Clavulanate on surface water at a concentration of $520 \mathrm{ng} \mathrm{L}^{-1}$.

In marine environmental studies, mussels are frequently used due to their characteristics as bioindicator organisms and their potential to accumulate xenobiotics on their tissue (Pereira et al., 2014). In Brazil, the Perna perna species is the most used due to its abundance.

The biomarkers help on the early warning adverse effects of a compound. Among the biomarkers, through the neutral red retention time (NRRT) assay which assesses the stability of hemocytes lysossomal membrane has been used in environmental studies. The lysosome is the responsible organelle for encapsulation of xenobiotics, however, in the presence of a toxic compound, the lysosomal membrane permeability becomes brittle and all the absorbed content is extravasated to the cytosol of the cells (Lowe et al., 1994).

The aim of this study was to evaluate the cytotoxicity of Amoxicilin and Potassium Clavulanate, in isolated and associated forms, through the NRRT assay, which assesses the stability of lisossomal membrane in mussels Perna perna hemocytes.

\section{MATERIAL AND METHODS}

\section{Collection of water and organisms}

For the assays, natural marine water and mussels Perna perna from a farm in Toque Toque Grande, in São Sebastião, coastal city in São Paulo, were used.

Marine water was filtered in $120 \mu \mathrm{m}$ plankton net for removal of particles and then physicochemical parameters were adjusted: salinity $35 \pm 2$; dissolved oxygen $>5 ; \mathrm{pH} \geq 8.00$. The organisms were kept in a tank with flowing marine water.

\section{Solutions preparation}

Amoxicillin, Potassium Clavulanate and all reagents used were purchased from Sigma Aldrich Brazil.

The physiological saline solution was prepared in distillated water in a volumetric flask of $1 \mathrm{~L}$. The used reagents are described in Table 1. The $\mathrm{pH}$ was adjusted to 7.36 with addition of Sodium Hydroxide $(\mathrm{NaOH})$ or Hydrochloric Acid $(\mathrm{HCl})$.

Table 1 - Reagents used in the preparation of physiological saline solution.

\begin{tabular}{lc}
\hline Reagents & Mass (g) \\
\hline Calcium chloride & 1.47 \\
Sodium chloride & 25.48 \\
& \\
Potassium chloride & 0.75 \\
& \\
HEPES & 4.77 \\
Magnesium sulfate & 13.06 \\
Neutral Red & 0.028 \\
Dimethylsulfoxide & $1 \mathrm{~mL}$ \\
\hline
\end{tabular}

Stock solutions for each drug were prepared in the concentration of $1 \mathrm{mg} \mathrm{L}^{-1}$ in sea water.

\section{Cytotoxicity assay}

The assays were carried out in glass flasks with 9 organisms in $3 \mathrm{~L}$ of solution, in triplicate. During the assay the temperature was maintained at $22^{\circ} \pm 2^{\circ} \mathrm{C}$, photoperiod of $12 \mathrm{~h}$ light/dark, and organisms were not fed. The analysis of samples occurred in 24, 48 and $72 \mathrm{~h}$ with changes of solutions every $24 \mathrm{~h}$. The drugs concentrations are presented in Table 2 and the assay flowchart are described in figure 1 .

Table 2 - Amoxicillin and Potassium Clavulanate concentrations in isolated and associated forms.

\begin{tabular}{lc}
\hline Compound & Test concentration \\
\hline Amoxicillin & $1 \mathrm{ng} \mathrm{L}^{-1}, 5 \mathrm{ng} \mathrm{L}^{-1}$ and $10 \mathrm{ng} \mathrm{L}^{-1}$ \\
Potassium Clavulanate & $10 \mathrm{ng} \mathrm{L}^{-1}, 50 \mathrm{ng} \mathrm{L}^{-1}$ and $100 \mathrm{ng} \mathrm{L}^{-1}$ \\
& $4 \mathrm{ng} \mathrm{L}^{-1} \mathrm{Amox}+1 \mathrm{ng} \mathrm{L}^{-1} \mathrm{Clav}$ (I) \\
Amoxicillin (Amox) and & $40 \mathrm{ng} \mathrm{L}^{-1} \mathrm{Amox}+10 \mathrm{ng} \mathrm{L}^{-1}$ Clav (II) \\
Potassium Clavulanate (Clav) & $200 \mathrm{ng} \mathrm{L}^{-1} \mathrm{Amox}+150 \mathrm{ng} \mathrm{L}^{-1} \mathrm{Clav}$ (III) \\
\hline
\end{tabular}

Every $24 \mathrm{~h}$ was removed $0.5 \mathrm{~mL}$ of haemolymph from each organism utilizing hypodermic syringe containing $0.5 \mathrm{~mL}$ of physiological saline solution, and kept in $2 \mathrm{~mL}$ Eppendorf tubes. Subsequently, an amount of $40 \mu \mathrm{L}$ of each sample was transferred to slides, pre-treated with poly-L-lysine. The slides were placed in a humid, light-proof chamber for 15 minutes so the cells could adhere to it. After this time, the excess liquid was withdrawn and $40 \mu \mathrm{L}$ of NR solution $(10 \mu \mathrm{L}$ stock solution of neutral red dye in $5 \mathrm{~mL}$ of saline) were added. The slides remained in the chamber and, every 15 minutes, 


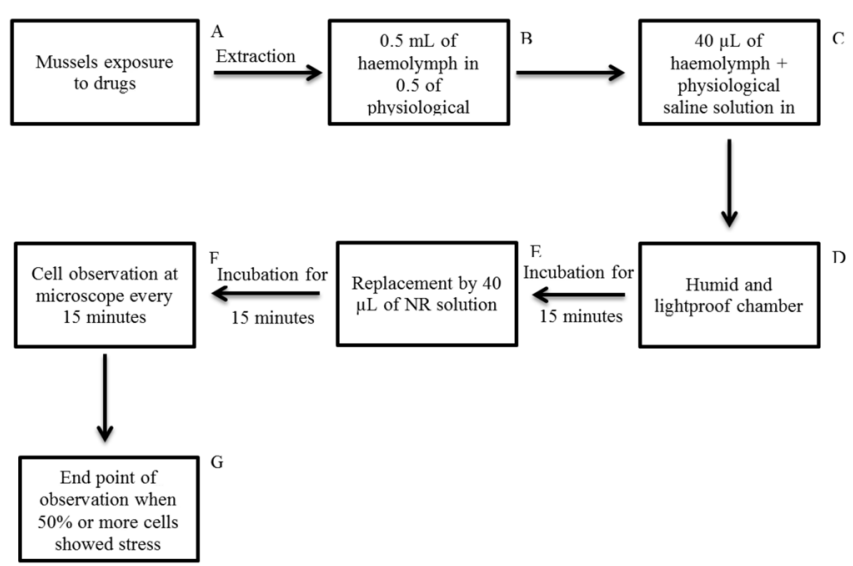

Figure 1 - Flowchart of NRRT assay

during 180 minutes, were analyzed in light microscope at 400x magnification, taking care to not expose excessively to light, to prevent photodegradation of the dye.

The results were placed in Tables using the evaluation criteria: "+" for healthy cells, " \pm " for those that showed signs of stress and "-" for $50 \%$ or more stressed cells and showing leakage of lysosomal content. The assay was concluded when all the slides presented "-" or after a period of 180 minutes. Images of healthy and stressed cells obtained in the assays are shown in figure 2 .

Cells accepted as healthy were those wide, irregular cells with many small lysosomes of light red color. The stressed cells had become rounded and smaller, few lysosomes in extended sizes, deep red color and dye extravasation.

\section{Statistical analysis}

The average values of retention times were calculated and evaluated for normality by Chi-square method and homogeneity of variance by Bartlett's test. These data were placed on the statistical program TOXSTAT 3.5 to obtain the observed effect concentration (OEC) which is the lowest test concentration capable to cause adverse effects, and the non-observed effect concentration (NOEC), which is the highest concentration-test that does not cause adverse effects. The damage caused by drugs was also presented by $25 \%$ Inhibitory Concentration $\left(\mathrm{IC}_{25}\right)$, the drug concentration which inhibit $25 \%$ of lysosomal membrane stability measured by the NRRT assay. The $\mathrm{IC}_{25}$ were calculated and evaluated by linear interpolation method in ICPIN statistical program.

\section{RESULTS AND DISCUSSION}

\section{Amoxicillin}

In the assay period of $24 \mathrm{~h}, 48 \mathrm{~h}$ and $72 \mathrm{~h}$ Amoxicillin caused cytotoxicity to mussels in all concentrations to which the organisms were exposed. Thus, in the experimental used conditions, it was not possible to calculate the non-observed effect concentration (NOEC) for this compound. Table 3 shows $\mathrm{IC}_{25}$ data with confidence intervals and coefficient of variation during the exposure times of the mussels to Amoxicillin and Figure 3 present the results graphically. In the figure 3 it was observed that with the increasing concentration of Amoxicillin there was decreasing of the retention time.

Amoxicillin is frequently described in the literature as a compound that does not interfere significantly with nontargets organisms, once this drug toxicity has a concentration level of $\mathrm{m} \mathrm{L}^{-1}$, that are not likely to occur in the environment. Among the tests carried out with Amoxicillin are:

i) Algal growth inhibition assays with Microcystis aeruginosa, $\mathrm{EC}_{50}=0.037 \mathrm{mg} \mathrm{L}^{-1}$, Selenastrum capricornutum, $\mathrm{NOEC}>250 \mathrm{mg} \mathrm{L}^{-1}$, Rhodomonas salina, $\mathrm{EC}_{50}=3.108 \mathrm{mg}$ $\mathrm{L}^{-1}$ and Synechococcus leopoliensis, $\mathrm{EC}_{50}=2.22 \mu \mathrm{g} \mathrm{L}^{-1}, \mathrm{CEO}=$ $1.56 \mu \mathrm{g} \mathrm{L}^{-1}$ and $\mathrm{NOEC}=0.78 \mu \mathrm{g} \mathrm{L} \mathrm{L}^{-1}$ (Lutzholft et al., 1999; Andreozzi et al., 2004).

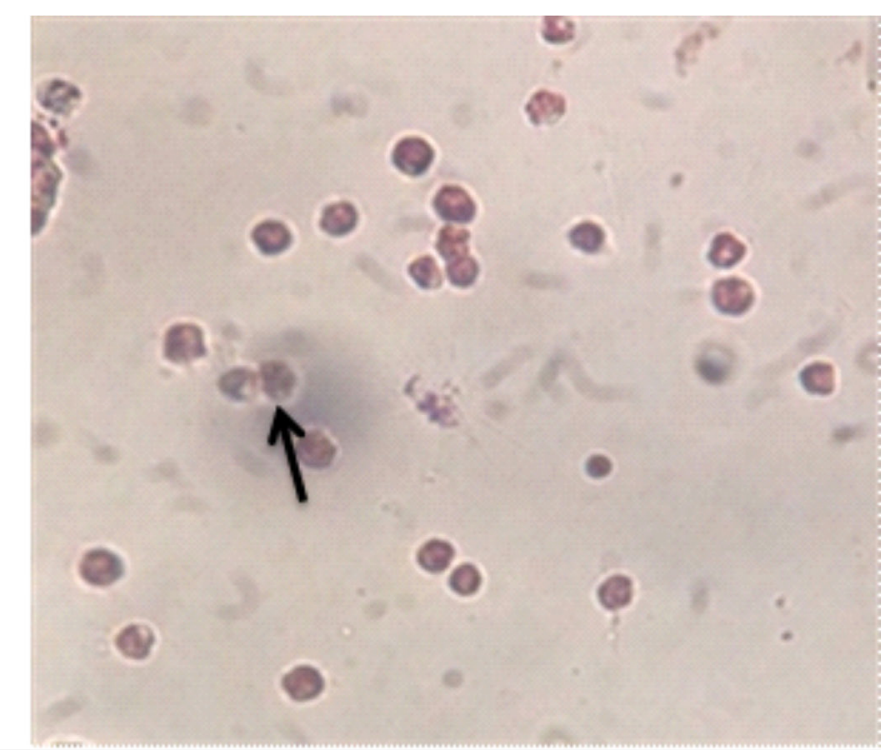

Figure 2 - Healthy and stressed cells (arrow), observed in the optic microscope (400x). 
Table 3 - Amoxicillin Inhibitory Concentrations $\left(\mathrm{IC}_{25}\right)$ data.

\begin{tabular}{|c|c|c|c|}
\hline Period & $\begin{array}{c}\mathrm{IC}_{25} \text { average value } \pm \mathrm{SD} \\
\left(\mathrm{ng} \mathrm{L}^{-1}\right)\end{array}$ & Confidence limit & $\mathrm{VC}(\%)$ \\
\hline $24 \mathrm{~h}$ & $0.44 \pm 0.04$ & $0.370-0.522$ & 10 \\
\hline $48 \mathrm{~h}$ & $1.19 \pm 0.91$ & $0.536-4.125$ & 77 \\
\hline $72 \mathrm{~h}$ & $0.85 \pm 0.09$ & - & 10 \\
\hline
\end{tabular}

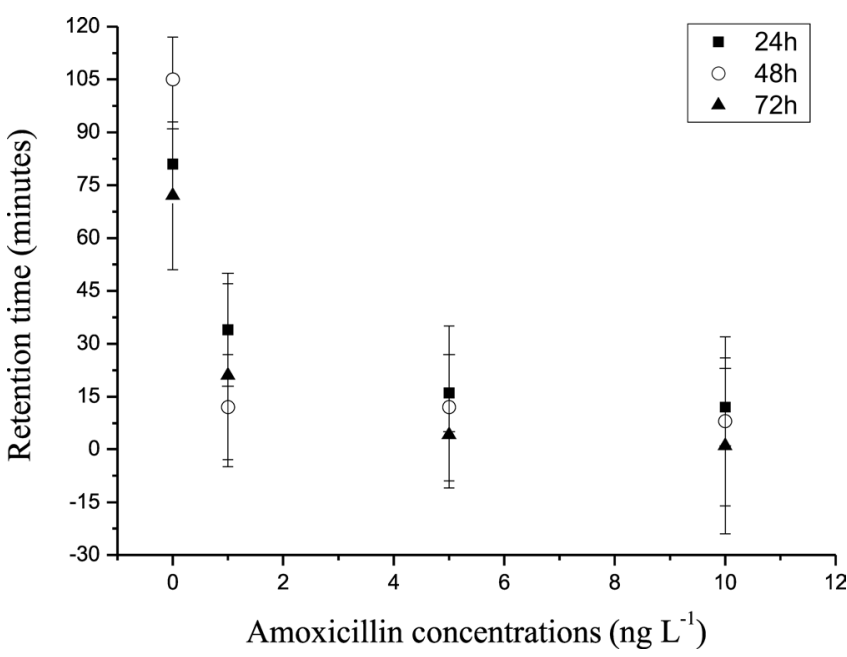

Figure 3 - Graphical representation of retention time in relation to Amoxicillin concentration.

ii) Evaluation of photosynthesis steps of Synechocystis sp. with damage from $50 \mathrm{mg} \mathrm{L}^{-1}$ (Pan et al., 2008).

iii) Studies with zebrafish, Danio rerio: embryos premature hatching $\left(\mathrm{EC}_{50(48 \mathrm{~h})}=132.4 \mathrm{mg} \mathrm{L}^{-1}\right)$, edema and deformities in the tail at concentrations of $221 \mathrm{mg} \mathrm{L}^{-1}, 380 \mathrm{mg} \mathrm{L}^{-1}, 654 \mathrm{mg} \mathrm{L}^{-1}$ and $1.125 \mathrm{mg} \mathrm{L}^{-1}$, inhibition of catalase enzyme in tissues of the head and gills, as well an increase of glutathione S-transferase in tissues of adult muscle and gills exposed organisms to $1 \mathrm{mg}$ $\mathrm{L}^{-1}$ (Oliveira et al., 2013).

iv) Effects on embriolarval of Perna perna mussels development, $\mathrm{OEC}=1000 \mathrm{mg} \mathrm{L}^{-1}$ and $\mathrm{IC}_{50}=835 \mathrm{mg} \mathrm{L}^{-1}$ (Bento, 2015).

However, the present study showed that concentrations in the order of ng $\mathrm{L}^{-1}$ of Amoxicillin caused cytotoxicity to mussel's hemocytes by the NRRT assay. These results are very similar to the occurrence in the environment such as the surface water in Northwest Germany $<10 \mathrm{ng} \mathrm{L}^{-1}$ (Christian et al., 2003), sewage treatment plant in Italy $>120 \mathrm{ng} \mathrm{L}^{-1}$ (Andreozzi et al., 2004) and affluent wastewater in Australia $190 \mathrm{ng} \mathrm{L}^{-1}$ (Watkinson et al., 2007), which demonstrates the risk of this antibiotic on the aquatic system.

\section{Potassium Clavulanate}

Potassium Clavulanate caused cytotoxicity to mussels at concentration of $10 \mathrm{ng} \mathrm{L}^{-1}$ in $24 \mathrm{~h}$ and $48 \mathrm{~h}$ periods. Under the experimental conditions used it was not possible to calculate the NOEC. At $72 \mathrm{~h}$ the cytotoxic concentrations were $50 \mathrm{ng} \mathrm{L}^{-1}$

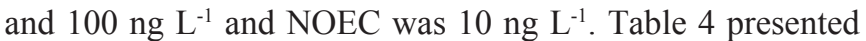

$\mathrm{IC}_{25}$ data with confidence intervals and coefficient of variation during the exposure times of the mussels to Potassium Clavulanate and Figure 4 presented the results graphically.

The environmental data for Potassium Clavulanate are scarce once the major part of studies are focused on the medical area. The result obtained in this paper was toxic; so the level of concentrations was about 50 times more toxic than in the paper of Besse \& Garric (2008) that presented the result of environmental prediction $\left(520 \mathrm{ng} \mathrm{L}^{-1}\right.$ in superficial water in France). These results demonstrated that it is necessary further studies about this compound and the possible damages to organisms.

\section{Amoxicillin and Potassium Clavulanate}

The assay carried out with the mixture of Amoxicillin and Potassium Clavulanate presented cytotoxicity to organisms in all test-concentrations in $48 \mathrm{~h}$ and, in these experimental conditions used, the NOEC were not possible to be calculated. In $72 \mathrm{~h}$ only the lowest mixture concentration of Amoxicillin $1 \mathrm{ng} \mathrm{L}^{-1}+$ Potassium Clavulanate $4 \mathrm{ng} \mathrm{L}^{-1}$ was not cytotoxic to mussels. Table 5 and 6 presents $\mathrm{IC}_{25}$ data with confidence intervals and coefficient of variation during the exposure times of the mussels to association of Amoxicillin and Potassium Clavulanate and Figure 5 shows the graphical results.

In the figure 5 it was observed that retention time decreased with the increasing concentrations and exposition period of Amoxicillin and Potassium Clavulanate. The drugs in

Table 4 - Potassium Clavulanate Inhibitory Concentrations $\left(\mathrm{IC}_{25}\right)$ data.

\begin{tabular}{lccc}
\hline Period & $\begin{array}{c}\mathrm{IC}_{25} \text { average value } \pm \mathrm{SD} \\
\left(\mathrm{ng} \mathrm{L}^{-1}\right)\end{array}$ & $\begin{array}{c}\text { Confidence limit } \\
\mathrm{VC}(\%)\end{array}$ \\
\hline $24 \mathrm{~h}$ & $3.11 \pm 0.29$ & $2.763-3.654$ & 9 \\
$48 \mathrm{~h}$ & $3.45 \pm 0.35$ & $2.920-4.156$ & 10 \\
$72 \mathrm{~h}$ & $3.43 \pm 0.24$ & $3.139-4.113$ & 7 \\
\hline
\end{tabular}

$\mathrm{SD}=$ Standard desviation $; \mathrm{VC}=$ Variation coefficient

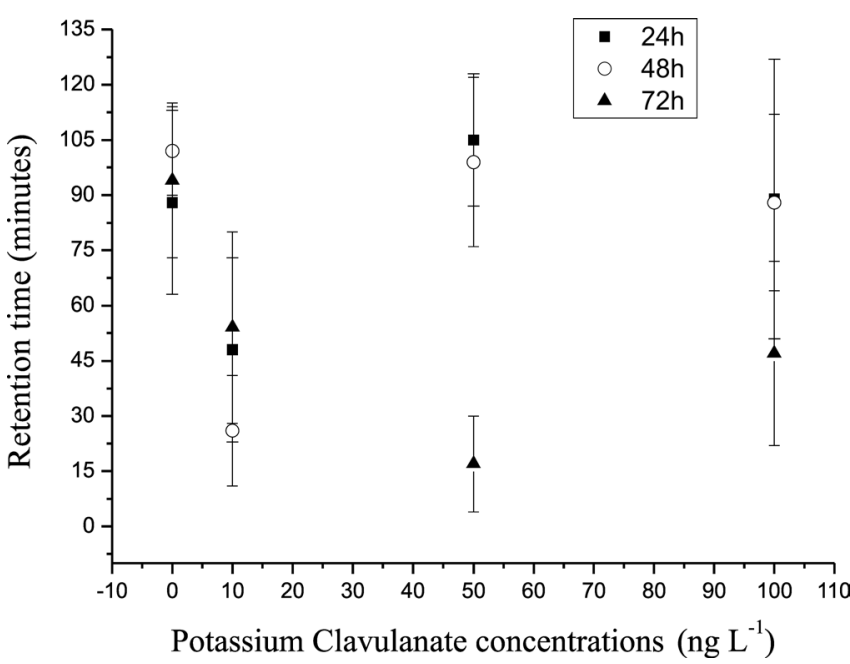

Figure 4 - Graphical representation of retention time in relation to Potassium Clavulanate concentrations. 
association presented more toxicity than when tested isolated in the cytotoxicity test by NRRT method.

The toxic potential of these drugs and cytotoxic results are possibly related to the degradation of them. Amoxicillin and Potassium Clavulanate have a low half-life, approximately 1 hour, and are more stable under acidic conditions. Thus, the alkalinity of the sea water used in the assays, and high water solubility of these drugs favored the decomposition and byproducts formation. Amoxicillin generates penicilloic acid and phenol hidroxipirazin in the early stages of decomposition. From the penicilloic acid formed the peniloic acid and 2',5'- diketopiperazine. Potassium Clavulanate forms pyrazine (Haginaka et al., 1985; Gozlan et al., 2013). The lack of data on the effects of these byproducts makes it difficult to conduct a larger discussion.

The application of NRRT assay to drug toxicity for mussels was successful, with efficient responses about effects of Omeprazole, Ibuprofen, Diclofenac and Paracetamol (Mathias et al., 2012; Gaspar, 2015; Mazur, 2015; Fontes et al., 2015).

The lysosome is the first cell organelle affected by the presence of xenobiotics, since its mechanism of action is to encapsulate these compounds as a cell defense, but, when

Table 5 - Inhibitory Concentrations $\left(\mathrm{IC}_{25}\right)$ data of Amoxicillin in the assay with Amoxicillin and Potassium Clavulanate association.

\begin{tabular}{lccc}
\hline Period & $\begin{array}{c}\mathrm{IC}_{25} \text { average value } \pm \mathrm{SD} \\
\left(\mathrm{ng} \mathrm{L}^{-1}\right)\end{array}$ & Confidence limit & $\mathrm{VC} \mathrm{( \% )}$ \\
\hline $48 \mathrm{~h}$ & $1.67 \pm 0.15$ & $1.46-2.04$ & 9 \\
$72 \mathrm{~h}$ & $1.36 \pm 0.09$ & $1.22-1.56$ & 7 \\
\hline
\end{tabular}

$\mathrm{SD}=$ Standard desviation $; \mathrm{VC}=$ Variation coefficient

Table $6-\mathrm{IC}_{25}$ data of Potassium Clavulanate to assay with Amoxicillin and Potassium Clavulanate association.

\begin{tabular}{lccc}
\hline Period & $\begin{array}{c}\mathrm{IC}_{25} \text { average value } \pm \mathrm{SD} \\
\left(\mathrm{ng} \mathrm{L}^{-1}\right)\end{array}$ & Confidence limit & $\mathrm{VC}(\%)$ \\
\hline $48 \mathrm{~h}$ & $0.42 \pm 0.05$ & $0.35-0.52$ & 12 \\
$72 \mathrm{~h}$ & $0.34 \pm 0.02$ & $0.30-0.39$ & 6 \\
\hline
\end{tabular}

$\mathrm{SD}=$ Standard desviation $; \mathrm{VC}=$ Variation coefficient

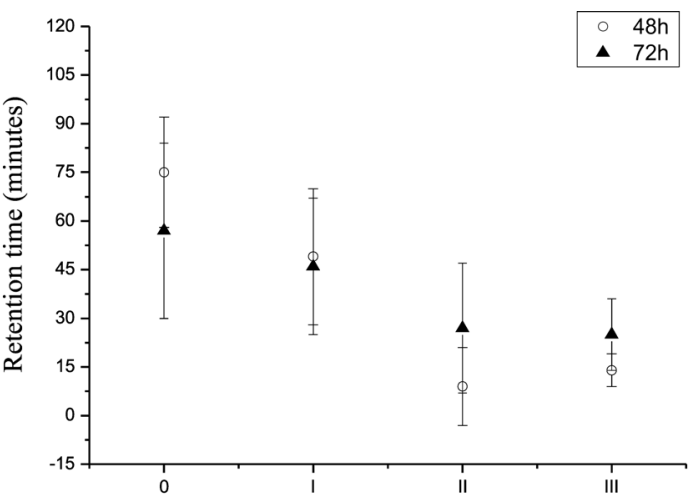

Concentrations of Amoxicillin and Potassium Clavulanate association (ng L ${ }^{-1}$ )

Figure 5 - Graphical representation of retention time in relation to the concentrations of Amoxicillin and Potassium Clavulanate association. there is continuous exposure to a disturbing homeostasis agent, damage becomes irreparable and the entire function is compromised, which may cause cell death (Lowe et. al, 1995).

The socioeconomic factor actions of pharmaceuticals compounds in the environment should be considered, especially to antibiotics, which are related to bacterial resistance. Zhang et al. (2009) collected samples of wastewater effluents and in the receiver river of this material in the United States; strains isolated of Acinetobacter spp from collection sites, and verified that almost all strains were resistant to antibiotics Trimethroprim, Rifampicin, Chloramphenicol and Amoxicillin with Potassium Clavulanate. In Rio de Janeiro, Brazil, the Oswaldo Cruz Foundation (Fiocruz) (2014), detected a bacteria that produce KPC enzyme (Carbapenemase) in different points of the Carioca River, which flows into the Flamengo Beach. These bacteria were also found in hospitals and presented high resistance to administered treatments, being responsible for the death of many patients.

Prevention and mitigation measures are needed to decrease improper discharge of compounds and the conscious use of drugs. It is necessary to remember that the focus of this study was only Amoxicillin and Potassium Clavulanate interactions, but the degradation compounds, formation of byproducts and association which can occur in the environment are issues that need more investigation to be further elucidated.

\section{CONCLUSION}

The antibiotics Amoxicillin and Potassium Clavulanate showed cytotoxic effect to Perna perna mussels in the cytotoxicity assay by NRRT method. The drugs presented about four times more toxicity in association than when tested isolated.

The NRRT biomarker is a good indicator of adverse effects, with accurate results that allows verify the compounds toxic potential to organisms and aquatic environment.

The mussels are good models of environment indicators due to their sensibility, easy handle, obtainment and representativity to biota.

This study allowed to determinate the drugs toxicity, an important result to prevent environment damages. These data could be complemented with analysis of compounds environmental risks, and could contribute to future aquatic environment ecotoxicity decision.

\section{ACKNOWLEDGEMENTS}

The author thanks CNPq for the scholarship which enabled the project realization.

\section{REFERENCES}

ANDREOZZI, R., CAPRIO, V., CINIGLIA, C., DECHAMPDOREA, M., LO GIUDICE, R., MAROTTA, R \& ZUCCATO, E. 2004. Antibiotics in the Environment: Occurrence in Italian STPs, Fate, 
and Preliminary Assessment on Algal Toxicity of Amoxicillin. Environ. Sci. Technol., 38: 6832-6838. http://dx.doi.org/10.1021/ es049509a

BENTO, N. R. 2015. Avaliação ecotoxicológica dos fármacos Fluoxetina e Amoxicilina empregando o mexilhão marinho Perna perna (Linnaeus 1758). MSc dissertation. Universidade Santa Cecília, Santos, 52p.

BESSE, J-P. \& GARRIC, J. 2008. Human pharmaceuticals in surface waters. Implementation of a prioritization methodology and application to the French situation. Toxicology Letters, 176: 104-123. http://dx.doi.org/10.1016/j.toxlet.2007.10.012

BILA, D. M. \& DEZOTTI, M. 2003. Fármacos no meio ambiente. Quím. Nova, 26(4): 523-530. http://dx.doi.org/10.1590/S010040422003000400015

CHRISTIAN, T.; SCHNEIDER, R. J.; FÄRBER, H. A.; 2003. SKUTLAREK, D.; MEYER, M. T.; GOLDBACH, H. E. 2003. Determination of Antibiotic Residues in Manure, Soil, and Surface Waters. Acta hydrochim. hydrobiol., 31(1): 3644. http://dx.doi.org/onlinelibrary.wiley.com/doi/10.1002/ aheh.200390014

COOPER, E. R.; SIEWICKI, T. C. \& PHILLIPS, K. 2008. Preliminary risk assessment database and risk ranking of pharmaceuticals in the environment. Science of the total environment, 398: 26-33. http://dx.doi.org/10.1016/j.scitotenv.2008.02.061

INSTITUTO OSWALDO CRUZ (FIOCRUZ). Superbactéria é encontrada em rio que deságua na praia do Flamengo (RJ). 2014. http://portal.fiocruz.br/pt-br/content/superbacteria-eencontrada-em-rio-que-desagua-na-praia-do-flamengo-no-riode-janeiro

FONTES, M.; ABESSA, D. M.; MAZUR, W.; NOBRE, C. R.; SOUZA, A.; MORENO, B. B.; CORTEZ, F. S.; PUSCEDDU, F. H. \& SEABRA, C. 2015. Effects of Diclofenac to the mussel Perna perna (Linnaeus, 1758): a preliminary environmental risk assessment in Santos bay (Brazil). 2014. Setac Latin American $11^{\text {th }}$ Biennial meeting, Buenos Aires, p. 85 .

GASPAR, J. C. 2015. Avaliação ecotoxicológica do fármaco Ibuprofeno: uma abordagem com múltiplos endpoints em parâmetros reprodutivos. MSc dissertation. Universidade Federal de São Paulo, Santos, 57p.

GOZLAN, I; ROTSTEIN, A. \& AVISAR, D. 2013. Amoxicillindegradation products formed under controlled environmental conditions: Identification and determination in the aquatic environment. Chemosphere, 91: 985-992. http://dx.doi. org/10.1016/j.chemosphere.2013.01.095

HAGINAKA, J.; YASUDA, H.; UNO, T. \& NAKAGAWA, T. 1985. Degradation of clavulanic acid in aqueous alkaline solution: isolation and structural investigations of degradation products. Chem. Pharm. Bull., 33, 218. http://dx.doi.org/10.1248/ cpb.33.218

KÜMMERER, K. 2009. Antibiotics in the aquatic environment - A review - Part I. Chemosphere, 75: 417-434. http://dx.doi. org/10.1016/j.chemosphere.2008.11.086

LEE, Y-J.; LEE, S-E.; LEE, D-S \& KIM, Y-H. 2008. Risk assessment of human antibiotics in Korean aquatic environment. Environmental Toxicology and Pharmacology, 26: 216-221. http://dx.doi.org/10.1016/j.etap.2008.03.014

LOWE, D. M. \& PIPE, R. K. 1994. Contaminant induced lysosomal membrane damage in marine mussels digestive cells: an in vitro study. Aquatic toxicology, 30: 357-365. http://dx.doi. org/10.1016/0166-445X(94)00045-X
LOWE, D. M.; SOVERCHIAB, C.\&MOORE, M.N. 1995.Lysosomal membrane responses in the blood and digestive cells of mussels experimentally exposed to fluoranthene. Aquatic Toxicology, 33: 105-112. http://dx.doi.org/ 10.1016/0166-445X(95)00015-V

LÜTZHOLFT, H. H. C.; HALLING-SORENSEN, B \& JORGENSEN, S. E. 1999. Algal Toxicity of Antibacterial Agents Applied in Danish Fish Farming. Arch. Environ. Contam. Toxicol., 36: 1-6. http://dx.doi.org/link.springer.com/ article/10.1007/s002449900435

MATHIAS, A. J. C.; SOUZA, L. S.; CORTEZ, F. S.; PEREIRA, C. D. S. 2012. Avaliação dos efeitos tóxicos do fármaco Omeprazol sobre mexilhões Perna perna (Linnaeus, 1758). In XII Congresso Brasileiro de Ecotoxicologia, Porto de Galinhas - PE.

MAZUR, W. A. 2015. Avaliação do risco ambiental do fármaco Paracetamol na Baía de Santos, SP. MSc dissertation. Universidade Santa Cecília, Santos, 77p.

OLIVEIRA, R.; McDONOUGH, S.; LADEWIG, J. C. L.; SOARES, M. V. M. A.; NOGUEIRA, A. J. A. \& DOMINGUES, I. 2013. Effects of oxytetracycline and amoxicillin on development and biomarkers activities of zebrafish (Danio rerio). Environmental toxicology and pharmacology, 36: 903-912. http://dx.doi. org/10.1016/j.etap.2013.07.019

OZCENGIZ, G \& DEMAIN, A. L. 2013. Recent advances in the biosynthesis of penicillins, cephalosporins and clavams and its regulation. Biotechnology Advances 31: 287-311. http://dx.doi. org/10.1016/j.biotechadv.2012.12.001

PAN, X.; DENG, C.; ZHANG, D.; WANG, J.; MU, G. \& CHEN, Y. 2008. Toxic effects of amoxicillin on the photosystem II of Synechocystis sp. characterized by a variety of in vivo chlorophyll fluorescence tests. Aquatic Toxicology 89: 207-213. http://dx.doi.org/10.1016/j.aquatox.2008.06.018

PEREIRA, C. D. S.; ABESSA, D. M. S.; CHOUERI, R. B.; ALMAGRO-PASTOR, V.; CÉSAR, A.; MARANHO, L. A.; MARTÍN-DÍAZ, M. L.; TORRES, R. J.; GUSSO-CHOUERI, P. K.; ALMEIDA, J. E.; CORTEZ, F. S.; MOZETO, A. A.; SILBIGER, H. L. N.; SOUSA, E. C. P. M.; DEL VALLS, T. A. \& BAINY, A. C. D. 2014. Ecological relevance of sentinels' biomarker responses: A multi-level approach. Marine Environmental Research 96: 118-126. http://dx.doi. org/10.1016/j.marenvres.2013.11.002

REGITANO, J. B.; LEAL, R. M. P. 2010. Comportamento e impacto ambiental de antibióticos usados na produção animal brasileira. R. Bras. Ci. Solo, 34: 601-620. http://dx.doi.org/10.1590/S010006832010000300002.

SAUDAGAR, P. S.; SURVASE, S. A. \& SINGHAL, R. S. 2008. Clavulanic acid: A review. Biotechnology Advances, 26: 335$35.1 \mathrm{http} / / / \mathrm{dx}$.doi.org/10.1016/j.biotechadv.2008.03.002

WATKINSON, A. J.; MURBYC, E. J. \& COSTANZO, S. D. 2007. Removal of antibiotics in conventional and advanced wastewater treatment: Implications for environmental discharge and wastewater recycling. Water research, 41: 4164-4176. http:// dx.doi.org/10.1016/j.watres.2007.04.005

ZHANG, Y.; MARRS, C. F.; SIMON, C. \& XI, C. 2009. Wastewater treatment contributes to selective increase of antibiotic resistance among Acinetobacter spp. Science of the Total Environment, 407: 3702-3706. http://dx.doi.org/10.1016/j.scitotenv.2009.02.013

ZOU, S.; XU, W.; ZHANG, R.; TANG, J.; CHEN, Y \& ZHANG, G. 2011. Occurrence and distribution of antibiotics in coastal water of the Bohai Bay, China: Impacts of river discharge and aquaculture activities. Environmental Pollution 159: 2913-2920. http://dx.doi.org/10.1016/j.envpol.2011.04.037 